KENTE, 2019,

\title{
An Ecocritical Reading of Selected African Poems
}

\section{Moussa Traoré}

Department of English

University of Cape Coast, Ghana mtraore@ucc.edu.gh I

camillio73@gmail.com

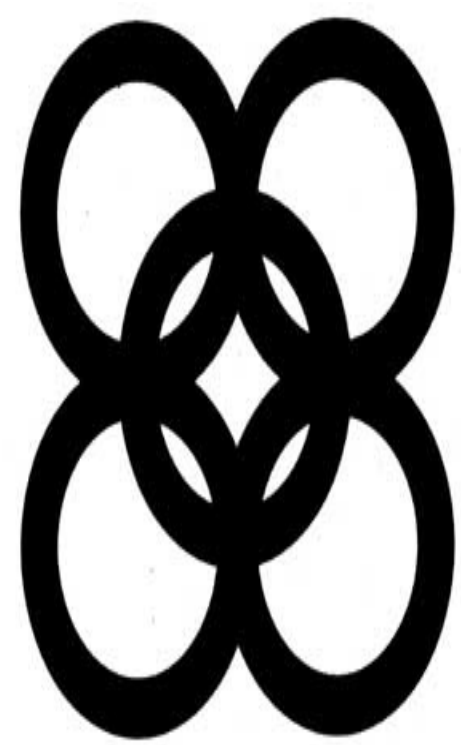

\begin{abstract}
This paper discusses some ecocritical ideas in selected poems by Kofi Awoonor, Kofi Anyidoho and the Negritude poets David Diop and Birago Diop. Drawing on postcolonial ecocriticism theory the paper focuses on ecocritical symbolisms and their ramifications in order to show how African poets attend to the environment, community and modernity's many flaws. The consideration of the Negritude poems in this study stems from the fact that Negritude Literature in general and the selected poems in particular have been examined mainly within the context of Black African identity and the antiracist effort in general. The paper demonstrates that ecological motifs or symbols are deployed by some African poets to express life, survival, and nostalgia.
\end{abstract}

\section{KEYWORDS}

Anthropological, Ecocriticism, Negritude, Poetic, Sustainability 


\section{Introduction}

In this essay, I am particularly interested in how African poets attend to the environment, the presence of community, and a pressing need to articulate criticisms of modernity's many flaws. The special way in which two Negritude poets, David Diop and Birago Diop use environmentrelated symbolism and metaphors like "the tree" among others is also one of the main points that this paper dissects; the environment is used by Negritude poets to render the beauty of African / black culture and also the negative side of colonization. Ecocriticism is the guiding thread of this work and Huggan \& Tiffin (2010) define ecocriticism as 'The exploration of conflicted areas and problems: wildlife protection and conservation on land needed for poor human communities; human communities evicted from their homeland to make way for game parks to benefit wealthy tourists; and, contained within these and other examples, a deep concern for rights' (p.18).To Ruby (2007), ecocriticism is a response to the need of a humanistic understanding of our relationships with the natural world in an age of environmental destruction. This article demonstrates that the environment and its sustainment is the preoccupation of some African poets such as Anyidoho and Awoonor, whose hometown (the Volta Region in Ghana) is experiencing the occupation of arable land by the sea and how this threatens human existence. The research also shows that some negritude poets use ecology to make the reader feel the destruction that colonization has meted to African culture. This paper therefore establishes a 'meeting point' between two Ghanaian poets and two Senegalese Negritude poets, through the environmental factor and ecocriticism.

In the poem, "The Cathedral", one of Awoonor's early poetic successes in his first book Rediscovery (1964), Kofi Awoonor presents an African reverence for nature testifying to the support and nurturing an ancient tree once gave to crops:

On this patch

a tree once stood

shedding incense on the infant corn

The "tree" eventually suffers displacement in favour of the cathedral identified in the poem's title. Though the poem is a critic of the abandonment of tradition, it highlights the true environmental impact of population growth and emerging ecological concerns from the second half of the twentieth century which threatened centuries old environmental legacies for transitory gains. Trees were revered in Africa as providers of comfort along journey routes and in homes. It is the dirty, fertile patches of land that trees called home. Thus, Awoonor offers to underlie the dirtiness of the patch or its fertility as necessary for the survival of trees, one of man's revered friends in nature. It was, therefore, unthinkable to destroy such an environmental asset without hurting a community. The dirty patch provided the fertility from which the tree shot into the skies.

Kofi Anyidoho also emphasises this environmental theme in "Agor", a poem in his recent book The Place We Call Home and other Poems (2011). This book is the most recent of his collection of poems which gives a new dimension to his writing: geopolitics and imperialism are engaged in poems like 'Bagdad', 'Desert Storm', and 'Countdown to Ground Zero', alongside traits of daily life in his native land in Ghana. In his mature and highly anthropological 
"Agor", Anyidoho shows that though the Royal Palm is a wind breaker in Ghanaian and Ewe popular culture, its struggles against the wind connote a contest for supremacy. But beneath this is a subtle social recognition that if the Royal Palm complains of the impetuous wind, then the less royal human will suffer great consequences once the Royal Palm is brought to its knees by Wind. He intelligently warns society of the environmental vulnerability it will be exposed to in the absence of natural defences like the Royal Palm. Anyidoho writes:

The Palm in his Royal Pride

Thinks

He can break the wind

and now he moans... he wails

The near acceptance of defeat, in the words of the Wind, shows just how the Royal Palm, a windbreaker for human homes, can be vulnerable. These species of trees and many others are diminishing by the day in the world and raising concerns about environmental sustainability.

At Keta, on the south-eastern shores of Ghana not far from Anyidoho's home, sea degradation of land has led to the intervention of the government to construct a sea defense wall. These kinds of near home environmental threats make Anyidoho's poetic reference to the environment relevant now and in the future. The verb "thinks" used alone in the second line above represents the false sense of hope man holds about his environmental future which is unfortunately a mirage. The poetry of these two men, therefore, hints not only at the ancient-ness of Africa's concern for the environment but warnings about the future human activities against the environment. Their concern for sustainability brilliantly echoes one of the key concerns of the Ghanaian government that is currently faced with environmental challenges: dwindling natural resources, arable lands engulfed by the sea on a daily basis, vertiginous climatic changes that impose suddenly new and worrisome weather patterns on people.

Ewe song and dirge traditions are symbiotically born out of its culture. In Ewe song and dirge traditions, the communality of the human experience is a guiding spirit to artistic compositions. Awoonor and Anyidoho dig deep into this aspect to give us poems that speak to the generality of the sense of community across African cultures. So in one sense, they both appeal to their Ewe cultural exposures and experiences from which they recount the oneness everyone feels in periods of joy and moments of pain as one big Ewe family. They further show that this communal representation among the Ewe is only a minute manifestation of the kind of strong sense of community in other cultures in Ghana like the Akan, Mole-Dagbani, Gonja, and GaAdangbe. While their poetics emerge from Ewe cultural practices associated with Ghana, it is also important to note that an emphasis on communal identity appears in other cultures of Africa. The communal emphasis can therefore be recognized on two planes: as a force grounded in Ewe expression, and as a unifying force across African traditions. In the poem, "Rediscovery", Awoonor (1964) presents that reality out in the very first stanza:

When our tears are dry on the shore and the fishermen carry their nets home and the seagulls return to bird island an the laughter of the children recedes at night, 
there shall still linger here the communion we forged, the feast of oneness which we partook of.

In this poem, he highlights a series of irremediable losses felt due to a lengthy, bonded sense of brotherhood in better days gone by. The end to these better days'(delete the apostrophe after days) halts with the fall of the cadence in line six. The communion which was forged makes the losses difficult to bear because the shore, which signifies death, separates the living from the departed ones. With the pronoun "we", the speaker highlights a participatory communal experience; one which brings the reader to feel the sensitivity of the community's losses and the difficulties of bearing the losses of individuals. Awoonor thus draws upon Ewe dirges to recount the unity and brotherliness that binds one to another in Ewe society. This specific Ewe communal identity and experience contribute to the validation of the broader African context of brotherliness and solidarity. Within an African context, the larger validation of communal identity allows Awoonor's Ewe dirges to gain a simultaneous, broader resonance.

Anyidoho buttresses the assertion of communal identities in his usage of the royal "we" and "us" in many dirges in his book, The Place We Call Home and other poems published in 2011. In the poem, "Atiegbon Legba", he uses the plural "we" to denote the unified action of a community of seekers facing an ultimate reality:

We are standing at the Crossroads

stranded

at the meeting point

of nightmare and DawnDream

still stranded

at the CrossWay

The worship he depicts is not an individual affair in African communities. Without this sense of communal engagement with the divine, the individual's own spiritual well-being is in doubt. He constructs joys, laments, and supplications for goodness in a language that highlights community feeling and togetherness revealed through the pronouns "we", "our", and "us".

In these ways, Awoonor and Anyidoho adopt the genre of poetry as a vehicle for the re-telling of an African story in a way that reminds us that people matter more than material or other gains. Viewed from an internationalised perspective where individuals often play greater poetic voices, a unique and key feature of the two poets' works is their eternal resistance to the use of the pronoun "I" when portraying communal experiences. They therefore call for an emphasis on, and a return to the principle of "We" and not "I".

Another commonality between Awoonor and Anyidoho is their willingness to speak about feelings and thoughts that many Africans desperately want to say or express, but cannot. An illustration lies in the fact that Awoonor was sent to prison by the military government of Ghana in 1975-76 for alleged anti-regime activities. These two poets have spoken about the social reality of poverty, corruption, and bad governance. They have especially used poetry to call to mind the many ill-fortunes of African cultures at the hands of Africans and foreigners. In "Go Tell Jesus", a poem which appears in his book The Place We Call Home and other poems, Anyidoho takes a critical stance against Christianity's meddling with the ordinary, traditional 
ways of life of Africans. In both the first and last four lines of the poem, Anyidoho states his main concern, which is the unintentional or purposeful distortion of Jesus' message, an act which ultimately marks the eruption of an avalanche of misfortunes for the African.

Go

Go tell Jesus

that his messengers have come

but have forgotten all His words

In the same poem, Anyidoho further highlights his criticisms of some Christian precepts as untrue and doubts if Jesus authorised those. This is captured in stanza two of the poem:

\author{
Go \\ Go ask Jesus \\ whether He really said \\ we cannot reach our God \\ if we do not pass through Him \\ Tell Him to tell you \\ the fate of my ancestors \\ Who lived and died before \\ He the Christ was born \\ Will all of them be \\ Damned?
}

Anyidoho bemoans the loss of traditional values and relations between fathers and children, and amongst children due to what Jesus' messengers have preached to these screaming shrieking, burning... souls. He thus presents a succinct criticism of Judeo-Christian basis for life in modern Africa.

Throughout his literary career, Awoonor likewise points to the ills African communities have suffered and which also define African modernity. He, however, chooses to decry the flight of African people from the traditions of the fathers as in his poem "My uncle the divinerchieftain", published in the book The Promise of Hope: New and Selected Poems, 1964-2013 (2014). The following stanza captures it:

They all left you, the young ones, the children you never had, the sons you dreamt up filling your earth-space

Awoonor elicits the element of desire in the mind of the patriarch, in "My uncle the diviner-chieftain", to show the expectations indigenous ways demand of younger ones. This indirectly questions the new modes of lifestyles, attitudes and practices many African young people have followed to the detriment of their own culture and identity. It also stresses that young Africans have been encouraged to leave their local communities to travel abroad in most cases. Thus, a subtle criticism of modernity and its evils is made. These criticisms of society's changing norms and values are aimed at calling attention to the need to not forget the starting point of our cultural and spiritual journey in our quest to hurriedly get to the cultural and spiritual 
destination we desperately seek. One can also grasp here the following message, being implicitly sent to the young generation of Africans by the two poets; the essence of that message can be put this way: It is beneficial to go abroad and acquire exposure, learn new things but do not forget to come back home and put into practice what you have acquired abroad. Each of them has studied outside, Kofi Awoonor studied in the UK and Kofi Anyidoho studied in the US and they all came back to Ghana, to teach in universities where among other tasks, they devoted ample energy, time, concern and attention to the Ewe literature and culture. They are therefore calling for an attitude similar to Antonio Gramsci's concept of "organicity" in his Prison Noteboooks (1971), which advocates that one can embrace new cultures while remaining rooted in one's "native culture".

The notion of "space" is of primordial importance in this study. Kofi Awoonor and Kofi Anyidoho hail from the same geographical location, the Volta Region in Ghana, and they succeed in their poems in extrapolating the notion of space to the spatio-temporal by visiting important dates, epochs and events that occurred in their community. One of the unique characteristics of these two poets' works is their use of time and space to demonstrate that what happens in their native Volta Region of Ghana applies to other parts of the African continent. Space is, therefore, the relatively limited starting spot or point which gradually leads to the wider common and general place, time and events. The effects of time and space on human life in Africa in particular and the whole world in general are pondered, to a modest extent, since issues like the environment, religion and migration that run across their poems are not limited to the Volta Region of Ghana, or Africa.

At this level, one can state that the impact of the complete works of late Kofi Awoonor and his compatriot Kofi Anyidoho is still to be assessed. Here I have sought to unveil key features of their poetics, considering the journeys they initiated for their local and regional community through time and space. These journeys are complex, as they comprise a language signaling intersections amongst Ewe cultural forces, a larger African cultural conversation, new environmental discourses, and ongoing reflections on the encounters between Africa, the West, and its corollaries. More extended studies must be done on these two writers.

The symbolic representation of the African community "Tree" and the connection between that symbol and the expression of nostalgia is also predominant in certain poems by Awoonor as well as some negritude poems by David Diop and Birago Diop. I find this to be an interesting overlap since not many studies point out the environment as one of the main concerns of Negritide poets.

In many African traditional societies, it is very common to find a special tree at the centre of a town, a village or a community, or sometimes, at a little distance from a settlement. In this paper, the term 'community tree' is preferably employed to distinguish it from multitudes of trees in the African forest in general. Again, the term 'community' is preferred for its sense of tribal settlements and township scattered across the continent prior to the colonial experience. Examples of community trees include the 'neem', the 'baobab', the silk-cotton, the 'palm' and several others, often located at the centre or vantage points in the communities/villages for their profound and varied significance. Such significance may be physical or spiritual to the life and existence of the individuals and the communities - the reasons for which the tribes establish their 
homes near or around the 'community tree'. The 'tree', therefore, belongs to the whole village as indicated for example that "Savannah communities have made their homes near Baobab trees. Every Baobab tree is community-owned and wild-harvested. No such thing as a Baobab plantation".

However, the cultural encounter between Africa and Europe, following the advent of the Europeans, suggests an apparent misconstruction of the relationship between the natives and these community trees by the Europeans. This sense is revealed in Kofi Awoonor's poems "The Cathedral" and "The Weaver Bird". In these poems, the Europeans 'cut' the 'tree' and 'planted' in its place a "senseless cathedral of doom" and 'built' their 'house' on the 'only tree' of the community. The question which obviously appears at this level is: "Why did the Europeans not choose any other place than the place where the tree stood?" Perhaps, the cause is attributive to a sheer disrespect for or misunderstanding of the African culture by the colonial masters. Each of these two possibilities, or even both, might precipitate the symbolic representation of 'the tree' by the post-colonial poets such as the Ghanaian, Kofi Awoonor, and the Senegalese David Diop and others, in the poems selected for this discussion, at least to re-assert the importance of the 'tree' to the natives who own it.

The rest of the essay is presented in two parts: The first part attempts to explore the physical and spiritual significance of the 'tree' at the centre of the African community. The second part focuses on the nostalgic feeling of the loss of the 'tree' and the clarion call for Africans to return to their root. Six African poems: "The Cathedral" and "The Weaver Bird" (Kofi Awoonor), "Africa" and "Vanity" (David Diop), "Abiku" (J.P. Clark) and "Vultures" (Birago Diop) are selected for analysis. However, reference is made to some secondary texts for the purpose of foregrounding. The ensuing sections discuss the community tree, the Europeans' attitude towards the 'tree'; and, the nostalgic effect of the cutting of the 'tree'.

\section{The community tree: Its association and significance in African traditional setting}

At this level, attention is focused on the practical usefulness of the 'tree(s)' often found within the settlements of African traditional societies. The physical and spiritual benefits of the 'tree' together with its metaphorical senses are explored.

According to Black (1995), "to know something about a tree--about even one tree--is to know something important, something fundamental, something profound about the nature of the world and our place in it" (p.1) Black notes that when a tree or trees grow within or around human settlements, the benefits derived from it /them include improvement of air quality, carbon sequestration, cooling, energy conservation, securing water supplies, noise reduction and erosion reduction. Among the trees commonly found in African traditional communities are the 'baobab', the 'neem', the 'silk-cotton' as well as the 'palm tree'.

The 'baobab', for instance, according to research conducted by Aduna which is an Africainspired health food brand and social business (online source), is a pre-historic species which predate both mankind and the splitting of the continent over 200 million years ago. Native to the African Savannah where the climate is extremely dry and arid, the 'baobab' has adapted to its environment. It is a succulent, which means during the rainy season, it absorbs and stores water in its vast trunk, enabling it to produce a nutrient-dense fruit in the dry season when all plants 
around it are dry and arid. It can provide shelter, food, and water for animals and humans-the reason the Savannah communities made their homes near 'baobab' trees. For this reason, it is described as "the tree of life". In Africa, there is no such thing as 'baobab' plantation since every tree is community or family owned and wild harvest, providing for several millions of households. Sun International (2014) indicates that apart from providing nourishment, the baobab features prominently in Africa literature and traditional folklores, with many stories making reference to its unique shape and meaning. It is believed that kings and elders held meetings under the baobab' tree, with the belief that the tree's spirits would guide them in their decision-making. Even in relatively modern Africa in the post-colonial era, the 'baobab' commonly serves as a venue for community meetings or even as a classroom where adults and children learn. It is believed that several spirits, good and evil indwell the 'baobab' tree.

The 'neem' tree is another tree whose significance is briefly explored in this paper. The 'neem' tree has been identified as one of the most important trees in arid regions of the world. From its roots to its spreading crown, the 'neem' contains a plethora of vital compounds useful for animals, humans and plants. It has numerous medicinal, cosmetic and agricultural importance bringing enormous benefits to countries both poor and rich. For this reason, the 'neem' tree is perceived as a "miracle" or "wonder" plant.

Even though this background information does not cover every single 'tree' located in the traditional communities of Africa, it provides some explanation for the place of the 'tree' in the culture and tradition of Africans. Apart from the numerous physical benefits of trees, they serve as shrines, meeting places, information and entertainment centres, and a link between the living and the unborn. In Chinua Achebe's Things Fall Apart, for example, the community "ilo"(the village gathering place and playing field; an area for large celebrations and special events where meetings, ceremonies (religious and social), and sports competitions take place) is the ground under the "ancient silk-tree" where meetings and entertainments such as wrestling take place. The ancient tree is sacred, and "Spirits of good children lived in that tree waiting to be born. On ordinary days, young women who desired children came to sit under its shade" (Achebe, 1958: 33). This, indeed, underscores the African natives' association and intimacy with the 'community tree' and its profuse representation in African poetry and other forms of literature, usually as a metaphor. Thus, in the poem 'The Cathedral', 'a tree' and 'that tree' symbolize the African culture, which was ruthlessly attacked or destroyed by the Europeans; in 'The Weaver Bird', "our only tree" represents Africa herself, as a continent and in David Diop's poem "Africamy Africa' (1956), "that tree young and strong" (1.18) symbolizes the young Africans scattered over the world who are growing physically and mentally strong.

\section{The Europeans' Attitude towards the 'tree': The ruthless attack on African culture.}

The attitude of the Europeans towards 'the tree' may be explained in terms of the sheer misinterpretation or misconstruction by the Europeans about the relationship between African communities and their environment. In the African communities, like all others in other parts of the world, including the western countries, tradition embodies "the accumulative body of knowledge, know-how, practices and representations maintained and developed by the peoples with extended histories of interaction with the natural environment" (Asian Social Science, p.2). Such interaction informs the people's set of understanding, interpretation, and meanings they 
assign to their practices, rituals, spirituality and general world-view. Obviously, African cultural practices are comprehended in the light of this perennial association with their environment. To understand the African culture, therefore, is to understand the Africans' relationship with their environment.

The fact, however, is that the colonialists together with the majority of the Christian missionaries seem to either fail to appreciate the culture of Africans or resolve to destroy the foundation of the African society in order to exploit the African continent. No one has so succinctly expressed the attitude of the Europeans towards the African culture more than Egudu (1978) who contends that

... the early Christian missionaries came to Africa not to sow the mustard seed of the Kingdom of God in the African cultural soil, but rather to sow the 'fire seed' which would burn up the 'grasses' of African culture ....To ensure that this unholy act against the cultures was accomplished... incarnated in birds of prey, the eagles, invaded the habitat of the 'sunbird' and the 'twin gods' who constitute the bedrock of these cultures (p.11).

In the six selected poems, together with other contemporary works, are found the reactions of many indigenous African poets and writers to the unfortunate cultural bias against Africa.

The first Ghanaian Ewe poet, to consider is Kofi Awoonor -- a postcolonial poet -- employs scatological imagery such as "excrement" to depict the western colonialism and culture, but uses the image of the "tree" and the "old shrines" to characterize the indigenous African religious culture. In his poems, "The Weaver Bird" and "The Cathedral", Awoonor satirically and scurrilously employs the theme of religion to register his vehement denunciation and repudiation of western colonialism and culture. In 'The Weaver Bird', the 'tree' is symbolic of Africa herself: "our only tree" (1. 2), and in "The Cathedral", the 'tree' symbolizes the African culture (1.2). The 'tree', in "The Cathedral", with its 'incense on the infant corn' (1.3), and the 'fires of a tribe' (1.5), is used as a symbol of the virile African culture (Umar, 2014). Thus, the 'tree' represents life and breath of the African tradition or religious culture.

Unfortunately, the Whiteman disrespectfully desecrated Africa and destroyed her rich and healthy culture. The poet's employment of the image of the "weaver bird" as symbol of the colonialists and Christianity, which they introduced seems appropriate. As a poetic symbol, the "weaver bird" connotes plunder and dirtiness and every other thing that is extremely evil. Besides, the sense of dirt is carried by the scatological imagery "excrement" of the "weaver bird" which has not only made the 'tree' dirty but, worst of all, desecrated the 'old shrines', where the natives offered sacrifices and worship to their gods and ancestors. The use of the filthy imagery is suggestive of Awoonor's profound disdain and abhorrence of the western colonialists and their religion which had engulfed the indigenous population. No wonder that the poet dropped his English name "William" to evince his rejection of the western culture. The 'weaver bird' image moreover suggests the poet's cynicism and disappointment about the western civilization. Umar, (2014) again suggests that the poet's placement of the two images, "excrement" and "dirty patch", in the poems "The Weaver Bird" and "The Cathedral" respectively may not only be seen as companion piece in their ugliness, but they also confer verbal seriousness and 'virtuoso' on his (Awoonor's) lyricism. 
Awoonor further intensifies his vehemence against the imperialist culture by thematizing conflict of culture, recurrently, in the poems. In both "The Weaver Bird" and "The Cathedral", he shows, unlike Léopold Sédar Senghor, for instance, that there is little or no room for reconciliation between western colonialism and African traditionalism. Both poems end in finality or irreconcilable conclusions. Whereas "The Weaver Bird" ends with the 'old shrines' defiled from the 'weaver's excrement', "The Cathedral" concludes with "a huge senseless cathedral of doom". Awoonor's reverence for Africa and her traditions is carried in his romanticizing Africa: "a tree once stood/shedding incense on the infant corn /its boughs stretched across a heaven" (The Cathedral' [1.2-4]) and "... in our house/...our only tree//we look for new homes every day/ for new altars we strive to re-build". ("The Weaver Bird" [1.1, 2, 14, 15]). The images of defilement which he employs to symbolize western colonialism evince his strong protest against the foreign culture and its pernicious effects.

Furthermore, nothing portrays ruthlessness and futility more than the images of destruction and robbery employed in these two poems of Awoonor. In "The Cathedral", "... surveyors and builders/...cut that tree." They just "cut that tree". Why would they not build the "cathedral' at a different ground other than where the 'tree' is located? Undoubtedly, they might know that that place was the heart of the natives. Besides, they might conceive that the natives were engaged in the worship of 'useless gods' under the 'tree' and therefore, getting rid of the 'tree' would mean getting rid of the people's religion and culture, which, in the Western worldview, had rendered the Africans heathen, pagan, primitive, unscientific, superstitious and uncultured. The colonizers might again guess that replacing the 'tree' with the 'cathedral', the latter would attract the heart of the natives as the former had done. In "The Weaver Bird" on the other hand, the "weaver bird" comes back claiming ownership of the land: "And the weaver bird returned in the guise of the owner" (1.6). What ingratitude! What robbery! Through this line, the poet foregrounds the greed, the ungratefulness and the destructive intention of the colonialists besides their disrespectful attitude towards Africa and her traditions. Colonization seems to denote disrespectfulness towards the colonized and all that they (the colonized) value.

\section{The nostalgic effect of the cutting of the "tree": The loss of naturalness.}

In his poetry, like his other contemporaries or predecessors such as David Diop and Birago Diop, Awoonor uses the poetic traditions of his native Ewe people to depict Africa during decolonization. He usually portrays western religion and culture as "lifeless" and African religion and culture as 'life' and 'health'. He does so through the use of imagery: 'tree' symbolizing African culture whilst 'cathedral', that is 'planted', represents the western culture. The reason for this portrayal or attitude of the poet is presumably the nostalgic feeling of loss experienced by the poet and the likes of him after the introduction of the European religion and culture. The poet cannot find the rich spirituality that Africans possessed prior to the advent of the new culture. This loss is heavily represented in "The Cathedral", "The Weaver Bird" and Birago Diop's "Vanity".

The "cathedral" itself, symbolizes not only the alien traditions of the Europeans which, in actual fact, are comparatively empty and meaningless and belong to the dead, but also, other changes that accompany the interruption of spiritual and commonly shared experience of the Africans 
with the 'tree'. Awoonor deepens the sense of loss of the experience with this 'tree', the true source of spirituality and the sense of communion with the ancestors, by contrasting the 'cathedral' with the 'tree'. Whereas the 'tree' is associated with numerous blessings to the local people, the 'cathedral' is linked with a sense of "doom" and uselessness. For instance, "a tree once stood/shedding incense...." (1.3) reflects the richness of African religious tradition. In African religious culture, incense is a holy substance useful for purification and perfuming which gives life and hope to the worshippers or the people (Okrah, 2014). The phrase "infant corn" (1.3) depicts life and abundance of food, promise of growth, life and hope for the future. This same 'tree' which "stretched its boughs across a heaven" (1.4), indicates a large and fulfilling spiritual and physical existence and shield or protection for the natives. It is important to note that the poet registers the loss of all these blessings through the use of past tense. This presupposes that the benefits enjoyed by the people were uninterrupted, in the past, until the "surveyors and builders" arrived, who "cut the tree" (1.7)," planting in its place" (1.8) the 'cathedral'. The progressive and arduous nature of the effort of replacing the 'tree' is reinforced by the present participle, 'planting'. Then, the builders' effort resulted in "A senseless cathedral of doom" (1. 9). Again, the cutting of the 'tree' is associated with the "the last fires" (1.5). The 'last fires' is symbolic of the last meal of the physical existence or last sacrifice to the ancestors/ gods. This represents an end to life or religion of the tribe (Africans) and thus, a loss of hope. The loss is further deepened by the sense that the 'tree', now cut or burnt and gone, has brought suffering, wars, conflicts and death to the people of that tribe (Africans) and, as well prevents them from progressing.

The poet's tone of anger and infuriation is portrayed by the choice of "dirty patch" (1.1) and "senseless cathedral of doom" (1.9). His anger is probably caused by the difficulty of grasping or figuring out why such a "senseless cathedral" should cause a lot of havoc to the people of the community. This sense is explicit in the last line (9) of 'The Cathedral':"the huge senseless cathedral of doom". This 'cathedral' brings 'doom' to the people in that it is the source and custodian of the colonial oppression and all its attendant evil. The "senseless cathedral" prevents Africans from practicing their own local culture and imposes coercively an alien culture on the people. One therefore realizes that Western missionaries classified Africans as a people who had no religious thoughts and imagination, no spiritual 'rootedness'; as a result, no preparation was deemed necessary before the propagation of the Gospel of Jesus Christ started and Africans were eventually made to accept a God who was alien. The western or foreign culture literally stole the Africans" freedom of worship from them. Awoonor criticizes the "they" for bringing 'doom 'to the people of the tribe. This view is strongly supported by Yeboah and Dargbazi (2012) that "as at the $21^{\text {st }}$ century, religious differences are the world's number one cause of conflicts and war on the African continent and others". This clearly underscores how important the 'tree', which unified the community at worship in the poet's native land, is to them Africans. It has been pointed out that the European missionaries separated their converts from the communities and settled them at the new place called 'Salem' to prevent them from associating and eating with their relatives who were 'unconverted'. They were often 'conscientised' at the Salem school to regard the 'unconverted' relatives and friends as evil and barbarians. They were as well brainwashed into the European culture and unquestioning subservience to colonization. This often generated conflict and division in the communities. No wonder Awoonor describes the 
'cathedral' as causing 'doom' to Africa. Similarly, the land on which the 'cathedral' is planted has lost its purity just as the 'tree' (Africa) on which the 'weaver bird' built its nest lost its beauty and cleanliness. It is now a 'dirty patch'. It has been desecrated by the casual 'planting' of the new religion and culture. How can anyone replace the ancient symbiosis of life and spirit that existed under that 'tree' from which the whole tribe drew their existence? The religion of the Africans means life to them whereas the imposed westernized religion means 'dead' or 'death'. Through the use of scatological imagery, Awoonor impresses on the mind of his readers that there is little justification for the imposition of a westernized religion and culture in the place or environment where the former freely grew. To Okrah (2014), the "cathedral" symbolizes not only the change in religious and spiritual experiences but also the purity of local fellowship (life) and freedom which was stolen by the imposition of the colonial government which in turn brought their religion by building a cathedral', a symbol of imperialist and colonial oppression which Awoonor sees as "senseless".

In "Vanity", Birago Diop, the Senegalese poet who spent most of his life in France, expresses the loss of the African culture by explicitly lambasting the thoughtless exuberance with which Africans themselves embrace the European culture. To him, this behaviour leads to what he regards as self-degradation emanating from a loss of cultural identity. The abandonment of the indigenous tradition only leads to "torments" (1.29), "clamouring" (1.30) and "sobbing" (1.31). In other words, the solution to the problems of Africa does not lie in the new imperfect culture but in the rich culture of the ancestors of the land. Thus, every effort of solving Africans problems or challenges by colonized method amounts to 'vanity'. The same sentiment is carried in David Diop's "The Renegade" in which he derides his fellow Africans who appear to be imitating the whiteman at the neglect of their own culture: "My brother you flash your teeth in response to every hypocrisy/... with gold-rimmed glasses/...give your master a blue-eyed faithful look/...in immaculate evening dress/screaming and whispering and pleading in the parlous of condescension/we pity you/ your country's burring sun is nothing but a shadow/ on your serene 'civilise' brow.../... a face that is bleached/ By years of humiliation and bad conscience" (1.1 - 8, 10 and 11). Diop strongly feels that Africans cannot desert their 'Africanness' and obtain favourable attention from the western eye. It is only a mockery for Africans to attempt to find such attention outside "your grandmother's hut" (1.9). In "The Weaver Bird", a parable about missionary intrusion and colonial under-development, Awoonor again highlights the relationship between the two ways in which the venally-minded constantly dressed up their foulest intentions in neat-fitting robes of benevolence. Fraser (1986) explains that the poet envisages a contrast between two religious systems; one securely earthed in the "old shrines" represented by the 'tree', and another which though proclaiming its presence in the language of God and enlightened self-knowledge, manages to bring in its train the yoke of tyranny. Of course, the latter is the colonizer, the 'weaver bird' desecrating the 'tree' (i.e. Africa). Even though both religions appear on the surface to enjoy a basic sincerity of intention in terms of their 'prayers', 'communicants' and 'altars', it is clear that in the effect of their ministration, the sharply differing aims become overt. The Africans "cannot join the prayers and answers of the communicants" (1.13) in the new religious expression, and still "... look for new homes everyday/for new altars... to re-build" $(1.14,15)$. Obviously, this reality of loss of spirituality and satisfaction explains the heavy presence of many Christians still trooping traditional shrines and 
prayer centres for "new homes" and "new altars". This is because, as Darkwa (2012) observes, "when such were confronted with the need to find solutions to the existential needs of life, they found their religion powerless to help. The missionaries therefore persistently lamented in discovering the patronage of the church members of anti-witchcraft cult shrines, which rose in the depression of the 1900s"(p.1). They seem not to have what they need in the foreign religious and cultural expressions. Africans deeply feel the loss of the 'tree' cut down by the 'builders' and desecrated by the "weaver bird's "excretion".

\section{The clarion call for African/cultural home-coming: Restoration of lost culture and identity.}

Generally, the Negritude movement has been noted for their expression of opposition to colonialism and assimilation by advocating African values and culture. Many poets in this movement thus couch their messages in bitterness and pessimism to at least, register their nostalgic feeling for the African past and culture. Nostalgia depicts sentimental longing or wistful affection for a period in the past.

In considering the strong nostalgia for home-coming and restoration of African culture, it is deemed apt to begin with David Mandessi Diop, one of the Negritude poets. Unlike several of his colleagues, Diop expresses hopefulness and comfort for exiles (actual and figurative) (Encyclopedia of World Biography, 2004). According to Cartey (2004), "within the body of each single poem Diop counterpoints notes of exile with recurrent chords of hope and return. Although within each poem harsh and gentle statements, negatives may alternate, Diop closes, almost without exception, on a note of optimism". Cartey overly rejects the idea that colonization had done anything positive for Africa and believes strongly that political freedom ought to take place before Africa could enjoy her own culturally and economic independence. David Diop asserts Africa's obstinate endurance and power to survive. His poems, therefore, create "a movement away from the negative effects of oppression to the positive possibility of regeneration in the poetic discovery of truth .... Hope springs from combat" (Cartey, 2004). In his works, Diop usually represents separation from Africa with a language suggesting agony, monotony, howls, metallic sounds and machine guns which Africa suffered under colonial rule.

For instance, in "Niger Tramp" or "Negro Tramp" (1956), a poem that Diop dedicated to Aimé Césaire who himself is one of the pillars of the Negritude movement, he employs the image of the derelict man as a symbol for Africa under the colonial rule and as well expresses pity for Africans who have submitted to the colonial will.

Diop again expresses an exile's cry, the feeling of homecoming in "Africa", which he dedicates to his biological mother. In this poem, he 'metaphorises' the African continent as his 'mother': "I have never known you/But your blood flows in my veins ("Africa", 1.5, 6). The above lines reveal the expression of the poet's eagerness to come home to his native land, Africa, and thus to his native culture. Diop's confidence and hope for Africa's recovery from her untoward humiliation is strongly and explicitly expressed in these lines: “...tell me Africa/is this your back that is unbent/This back that never breaks under the weight of humiliation/ This back trembling with red scars/ And saying no to the whip under the midday sun/ But a grave voice answers me/ Impetuous child that tree, young and strong/ that tree over there/ splendidly alone amidst white 
and faded flowers/ That is your Africa springing up anew/ springing up patiently, obstinately/ whose fruit bit by bit acquires/The bitter taste of liberty"(“Africa”, lines. 12-24).

In the above lines of "Africa", which constitute a dialogue or dramatic monologue, Diop appears to conjecture 'Africa' as someone with a bent back breaking "under the weight of humiliation". However, 'Africa' the poet's mother quickly reprimands him: "Impetuous child that tree, young and strong/that tree over there/... is your Africa springing up anew". No words or imagery so assuredly and succinctly repose confidence of renewal and triumph than those used by Diop. Though 'Africa' has endured pain and humiliation from the imperialists, she is obstinately renewing and regaining her lost glory--the 'tree' is developing new leaves and its flower wilting, giving hope of life and abundance. Restoration of her dignity and socio-economic glory is imminent.

The poem "Abiku" by J.R. Clark is another literary piece which implicitly but strongly induces a sense of return to African culture. The word "Abiku" is a Yoruba term referring to a child who repeatedly dies to be re-born again and again. Among the tribes in Nigeria, like several other tribes in Africa, an 'abiku' is believed to be a 'spirit child' and there are many of their kind living in the baobab tree. Literarily, it is one of these 'abikus' that the poet addresses, pleading with it to either decide to stay with the mother (the living) or "stay out on the baobab tree" (1.2). Generally, in traditional communities, the baobab tree is suspected to be the meeting place of all manner of spirits who work at night including the 'abiku'. By asking 'Abiku' to stay out on the baobab tree, the poet is asking the child to stay in the spirit world and not be reborn. 'Abiku' should thus "follow" where he pleases his "kindred spirits" (1.3) if "indoors is not enough" for him (1.4). The poet's basis for asking the Abiku to choose one place is that the mother's body is tired of his oscillation and again, her tribe has been a "healthy stock" for many people "who reach to the sun" (1.12-14). Underneath the poem's simple message, however, seemingly is a subtle and more implicit impression. It is commonplace to find many Africans, predominantly educated, whose life and behaviour(s) are outrageously informed by the European culture at the neglect of African tradition and culture but who from time to time, at their convenience resort to the latter selfishly and fleetingly.

The poet is passionate and honest. He outlines the modest condition of Africa. It "leaks through the thatch" (1.15), a roof of grass and straw used as matting for the poor home built often of day. When it rains, "floods brim the banks". (1.6) At night also, "bats and owls tear through the eaves" $(1.7,8)$ making sleep unpleasant and difficult. Yet, the place has been a "healthy stock" for "several fingers" reaching to the sun. Words such as "thatch", 'straw', 'clay', 'rains' 'floods' 'bats' and 'owls' are visual images representing poverty, hardship and vulnerability characterizing the Africa continent. The 'bats' and 'owls' which disturb the sleep of the people of the "poor mother's home" home probably symbolize the European intruders and colonizers of Africa. In addressing 'Abiku' this way, the poet appears to be inviting similarly the oscillating Africans to get settled in the continent and into its culture, since in it they can progress like the others who "reach to the sun" as Africa is a place "where many more mouths gladden the heart". ("Abiku”, 1.26).

\section{Conclusion}


This paper has revealed how some African poets connect thematic issues with environmental issues or environment-related metaphors. The poems of Kofi Awoonor have been discussed, because of their multifaceted features; they capture the threat behind the destruction of the environment and also the nostalgia for the past, as David Diop and Birago Diop do in their poems, when they express their anger at the unjust and erroneous way in which precolonial Africa has been objectified and presented as a land where no culture, civilization or religious beliefs exist; a land with no soul, where the white man's burden has to bring human values. Kofi Anyidoho's poems have also been examined, with a special focus on the devastation that the environment suffers in Eweland, where the land is claimed by the sea at an outrageous speed and it has also been pointed out that in Anyidoho's eyes, the destruction of African tradition culture by Westerners is presented as one of the tragedies that befell Africa, although Anyidoho's poetry delves into geopolitics and other topics which are of vital importance. Along the same line, the paper has demonstrated that in "The Cathedral", Kofi Awoonor laments the cutting of the "tree' which is the symbol of African religious culture and condemns its comparatively "useless" replacement, the 'cathedral of doom', the symbol of European colonization. The same sentiment is carried by Anyidoho in "The Weaver Bird" in which the 'tree' 'our only tree', the metaphor of Africa with its culture, is "desecrated" by the invader's "excrement", in their attempt to replace it with their "monument of tutelage" to inculcate Western colonialism or culture which is the white man's stamp of mental enslavement of Africa. In both poems, it is apparent that natives of Africa cannot find "meaning" and "sense" in the alien culture which replaces the "tree" and as such seek a restoration of their tree' and "old shrines".

This search finds expression in "The Weaver Bird" thus: "we look for new homes every day. I For new alters we strive to rebuild/ The old shrines defiled from the weaver's excrement". (1.15-17). In "Vanity" by Birago Diop the reader finds the cause of this 'cry' for the restoration of the lost culture: "our ears were deaf/ to the wild appeals" of our forefathers. Whilst David Diop's "The Vultures" expresses the poet's disappointment and the general seeming disillusionment of Africans in the European culture, and projects the strong feeling for return to African traditions, J.P. Clark's "Abiku" makes a strong appeal to Africans, who virtually demonstrate a loss of identity, to feel proud to return to their native identity or root. David Diop's role in Africa is to romanticize and project Africa in a most appealing manner.

This paper has demonstrated that the poets' use of symbolism is very effective and forceful in their expression of the deep sense of loss of culture, identity and the desire for the restoration of that culture. The uniqueness of the poets' achievement emanates from the use of the environment or "the tree" particularly, to put across the image of a culture and African world view which has been violated and trampled upon, and also, an issue of daily survival, which is the decimation of the ecosystem in the Volta Region in Ghana. 


\section{REFERENCES}

Abiku: “John Pepper Clark: Poet's Profile”. Available at https //afrilingual.wordpress.com. Retrieved on 11/12/2018

Achebe, C. (1958). Things Fall Apart. London: Heinemann.

ADUNA. Economic Benefits, Health and Beauty of the Baobab Tree. Available at a d u na.com/ pages/baobab tree. Retrieved on 11/12/2018

Amanor, J.D (2012). Pentecostalism in Ghana: An African Reformation. Available at www.pctiii.org/cyberj13/amanor.html. Retrieved on 11/12/2018

Anyidoho, K. (2011). The place we call home and other poems. Oxfordshire: Ayebia Clarke Publishing Limited.

Anyidoho, K. (2002). Praise song for the land: Poems of hope and love and care. Accra: SubSaharan Publishers. Asian Social Science Vol. 8, No. 7; June 2012 Available at www.ccsenet.org/ass

Awoonor, K. (1964) "The Cathedral". Rediscovery and Other Poems. Available at https:// www.poemhunter.com/poem/the-cathedral-4/. Retrieved on 11/12/2018.

Awoonor, K. (2014). The promise of hope: New and selected poems, 1964-2013. Lincoln: University of Nebraska Press.

Awoonor, K. (2014). “The Weaver Bird”. New and selected poem, 1964-2013. Poetry Foundation Web.

Awoonor, K. "The Weather Bird". Rediscovery and Other Poems. Available at https:// www.poemhunter.com/poem/kofi-awoonor- the-weaver-bird/Retrieved 11/12/2018 Diop, D. (1956). "Nigger Tramp". Coups de Pilon. Paris: Présence Africaine.

Diop, D. (1956) "Afrique mon Afrique" Translated as "Africa my Africa". Coups de Pilon. Paris: Présence Africaine.

Diop, D. (1976). "Vanity" in Senanu, K. E. and Vincent, T. (ed.) A Selection of African Poetry. England: Longman Group Ltd.

Diop, B. (1976). "The Vultures" and "Africa" in Senanu, K. E. and Vincent, T. (ed.) A Selection of African Poetry. England: Longman Group Ltd.

Egudu, R.N. (1978). Modern African Poetry and the African Predicament Macmillan: New York Encyclopedia of World Biography (2004). Diop, David Mandessi. The Gale Group Inc. 
Available at http://www.encyclopedia.com/doc. Retrieved on 11/12/2018. Univ. Press, Amazon (p. 162).

Gramsci, A. (1971). Prison Notebooks. London: Lawrence and Wishart.

Huggan, G., \& Tiffin, H. (2010). Postcolonial Ecocriticism: Literature. Animals, Environment. London and New York: Routledge.

Okrah, O. (2014). Images Portraying Western Religion as Lifeless In the Poem "The Cathedral" By Kofi Awoonor: Available at www.academia.edu. Retrieved on 11/12/2018

Ruby, G. (2007). Poems of Robert Frost - olkopoetic dimension. Available at http:// shodhganga.inflibnet.ac.in/handle/10603/116626 retrieved on 11/12/18.

Senanu, K.E \& Vincent, T. (1976). A selection of African poetry: Revised and enlarged edition.

UK: Longman Group Limitedhttps://afrilingual.worldpress.com Accessed on 21/06/2016

Sun International (2014). Fact and Folklore of Africa's Mighty Baobab Tree. Available at www.suninternational.com. Retrieved on 11/12/2018

Umar, I. (2014). Myth and Symbol in Kofi Awoonor's Poetic Art. Available at h t t p s : / / plus.google.com/+isunoyaUmarTheGlobeStreamFlow/posts/FSah8Cr4m78.

Retrieved on 11/12/2018.

Yeboah, S.A. and Dargbazi, S. African Literature: Discussing Thematic Concerns in "The Cathedral" of Awoonor and Other African Writers. Available at https://www.google.com/ search?safe=strict\&source $=$ hp\&ei. Retrieved on 11/12/2018. 